\title{
GAMBARAN PEMBERIAN TERAPI KEGEL EXERCISE TERHADAP INKONTINENSIA URINE PADA IBU POSTPARTUM
}

\author{
Descrption of Kegel Exercise Therapy on Urine Incontinensia in Woman \\ with Postpartum Normal
}

Aila Andani, Rusmala Dewi*, Madepan Mulia

STIKes Panca Bhakti

*Email korespondensi: ailaandani2899@gmail.com,

\begin{abstract}
ABSTRAK
Pendahuluan: Postpartum atau masa nifas adalah masa yang dimulai setelah kelahiran plasenta dan berakhir saat alat-alat kandungan kembali seperti keadaan sebelum hamil. Salah satu permasalahan pada ibu postpartum adalah inkontinensia urin. Inkontinensia urine merupakan ketidakmampuan seseorang untuk menahan keluarnya urine. Kegel exercise adalah tindakan non farmakologi yang dapat digunakan untuk memperkuat otot-otot dasar panggul. Tujuan penelitian ini adalah untuk mengetahui gambaran pemberian intervensi kegel exercise terhadap inkontinensia urin pada ibu postpartum di Wilayah Kerja Puskesmas Gedong Air Bandar Lampung. Metode penelitian menggunakan penelitian deskriptif. Penelitian ini melibatkan dua partisipan yaitu dua ibu postpartum. Instrumen yang digunakan adalah lembar observasi dan lembar kuesioner International Consultant Incontinence Questionnaire-Urine Incontinence Short Form (ICIQ-UISF). Hasil penelitian menunjukkan pada partisipan pertama tidak terjadi inkontinensia urin di hari keenam dan partisipan kedua tidak mengalami inkontinensia urin pada hari ketujuh. Berdasarkan hasil penelitian didapakan hasil bahwa teknik kegel exercise dapat direkomendasikan untuk mencegah terjadinya inkontinensia urin pada ibu postpartum. Saran: Direkomendasikan latihan kegel exercise pada ibu postpartum dapat diberikan untuk mencegah atau mengatasi inkontinensia urin
\end{abstract}

Kata kunci: Postpartum; Inkontinensia urine; Kegel exercise;

\begin{abstract}
Introduction: Postpartum or the puerperium is a period that begins after the birth of the placenta and ends when the uterus organs return to their pre-pregnancy state. One of the problems in postpartum mothers is urinary incontinence. Urinary incontinence is a person's inability to hold out urine. Kegel exercises are non-pharmacological measures that can be used to strengthen the pelvic floor muscles. The Aim of this study was to describe the provision of kegel exercise interventions on urinary incontinence in postpartum mothers in the Gedong Air Health Center in Bandar Lampung. The research method used is descriptive research. The research involving two participants, namely two postpartum mothers. The instruments used were the observation sheet and the International Consultant Incontinence Questionnaire-Urine Incontinence Short Form (ICIQ-UISF) questionnaire. The results showed that the first participant did not experience urinary incontinence on the sixth day and the second participant did not experience urinary incontinence on the seventh day. Based on the research results, it was found that the Kegel technique exercise can be recommended to prevent urinary incontinence in postpartum mothers. Suggestion: It is recommended that Kegel exercises for postpartum mothers be given to prevent or treat urinary incontinence
\end{abstract}

Keywords : Postpartum; urinary incontinence; kegel exercise;

https://doi.org/10.33860/mnj.v1i2.280

(C) 2020 by the authors. Submitted for possible open access publication under the terms and conditions of the Creative Commons Attribution (CC BY SA) license (https://creativecommons.org/licenses/by-sa/4.0/). 


\section{PENDAHULUAN}

Postpartum atau masa nifas adalah masa yang dimulai setelah kelahiran plasenta dan berakhir saat alat-alat kandungan kembali seperti keadaan sebelum hamil, masa nifas ini berlangsung sekitar 6 minggu. ${ }^{1}$ Percepatan pemulihan kondisi setelah melahirkan diperlukannya ambulasi dini dan berkemih 2 jam setelah postpartum. ${ }^{2}$ Ibu postpartum kadang mengeluhkan permasalahan pada sistem perkemihan di 24 jam pertama setelah melahirkan. Peran perawat yaitu mengidentifikasi kebutuhan fisiologis yang belum terpenuhi salah satunya adalah eleminasi urin. Berbagai permasalahan yang sering terjadi pada eleminasi urin seperti inkontinensia urin dan retensi urin. Inkontinensia urin adalah suatu keadaan seseorang yang tidak mampu menahan keluarnya urine. ${ }^{3}$

Inkontinensia urin merupakan keadaan yang dapat menimbulkan berbagai permasalahan seperti kesehatan, sosial ataupun ekonomi. Kejadian inkontinensia urin pada wanita sekitar 10-40\% dimana 4$8 \%$ mulai mencari bantuan pengobatan dengan kondisi yang sudah parah. Sebenarnya kejadian yang tercatat bukanlah angka yang sebenarnya karena sebagian dari yang mengalami inkontinensia urin tidak terdeteksi dikarenakan kondisi ini dianggap suatu kondisi yang tidak mengancam jiwa sehingga tidak perlu ditangani dengan segera dan ada juga yang tidak mau atau malu untuk mengungkapkan keluhan yang dirasakan. ${ }^{3}$

Setelah diidentifikasi masalah yang ada pada ibu hamil, perawat menentukan intervensi yang digunakan untuk mengatasi masalah tersebut. Penerapan terapi kegel exercise diberikan untuk meningkatkan kekuatan otot dasar panggul. Berdasarkan latar belakang tersebut, eneliti tertarik meneliti tentang gambaran pemberian terapi kegel exercise terhadap inkontinensia urine pada ibu postpartum Di Wilayah Kerja Puskesmas Gedong Air Bandar Lampung.

\section{METODE PENELITIAN}

Penelitian ini adalah penelitian kualitatif dengan desain studi kasus. Penelitian melibatkan 2 partisipan yaitu ibu postpartum di Wilayah Kerja Puskesmas Gedong Air Bandar Lampung. Penelitian dilakukan pada tanggal 31 Maret sampai dengan 20 Mei 2020. Instrumen yang digunakan dalam penelitian ini adalah lembar observasi kegel exercise dan lembar kuesioner International Consultant Incontinence QuestionnaireUrine Incontience Short Form (ICIQ-UISF) untuk menilai derajat inkontinensia urin.

\section{HASIL PENELITIAN}

Partisipan pertama berusia 24 tahun, beragama islam, pendidikan SMA, status obstetri P1A0. Partisipan kedua berusia 35 tahun, agama islam, pendidikan $\mathrm{SD}$, status obstetri P3A0.

Tabel 1.

Distribusi Partisipan Berdasarkan Derajat Inkontinensia Urin Sebelum Intervensi Kegel Exercise $(\mathrm{n}=2)$

\begin{tabular}{ccc}
\hline Partisipan & Skoring & $\begin{array}{c}\text { Derajat } \\
\text { Inkontinensia }\end{array}$ \\
\hline I & 10 & Ringan - Sedang \\
\hline II & 13 & Sedang \\
\hline
\end{tabular}

Berdasarkan tabel 1 di atas dijelaskan bahwa pada partisipan pertama tingkat inkontinensia urine sebelum dilakukan penerapan kegel exercise yaitu inkontinensia urine ringan - sedang dengan skor 10, sedangkan pada partisipan kedua tingkat inkontinensia urine sebelum dilakukan penerapan kegel exercise yaitu inkontinensia urine sedang dengan skor 13. 
Tabel 2

Distribusi Partisipan Berdasarkan Derajat

Inkontinensia Urin Sesudah Intervensi Kegel Exercise $(\mathbf{n}=2)$

\begin{tabular}{cccl}
\hline $\begin{array}{c}\text { Respon } \\
\text { den }\end{array}$ & $\begin{array}{c}\text { Hari } \\
\text { Ke- }\end{array}$ & Skoring & $\begin{array}{c}\text { Derajat } \\
\text { Inkontinensia }\end{array}$ \\
\hline I & 1 & 9 & Ringan-Sedang \\
& 2 & 7 & Ringan-Sedang \\
& 3 & 6 & Ringan \\
& 4 & 4 & Ringan \\
& 5 & 2 & \\
& 6 & 0 & Ringan \\
& 7 & 0 & Tidak Inkontinensia \\
& & & Tidak Inkontinensia \\
\hline II & 1 & 12 & Ringan-Sedang \\
& 2 & 9 & Ringan-Sedang \\
& 3 & 7 & Ringan-Sedang \\
& 4 & 6 & Ringan \\
& 5 & 4 & Ringan \\
& 6 & 2 & Ringan \\
& 7 & 0 & Tidak Inkontinensia \\
\hline
\end{tabular}

Berdasarkan tabel 2 di atas dijelaskan bahwa inkontinensia urine setelah intervensi pada hari ke-1 partisipan pertama skor 9 (ringan-sedang) dan partisipan kedua 12 (ringan-sedang), pada hari ke-2 partisipan pertama skor 7 (ringan-sedang) dan partisipan kedua skor 9 (ringan-sedang), pada hari ke-3 partisipan pertama skor 6 (ringan) dan partisipan kedua skor 7 (ringan-sedang), pada hari ke-4 partisipan pertama skor 4 (ringan) dan partisipan kedua skor 6 (ringan), pada hari ke-5 partisipan pertama skor 2 (ringan) dan partisipan kedua skor 4 (ringan), pada hari ke-6 partisipan pertama dan kedua skor 0 (tidak inkontinensia urine) serta pada hari ke-7 partisipan pertama dan kedua skor 0 (tidak inkontinensia urine).

\section{PEMBAHASAN}

Hasil penelitian pada kedua partisipan masing-masing pada partisipan pertama Ny.At berusia 24 tahun dengan riwayat persalinan P1A0, pendidikan SMA, beragama islam, berat bayi lahir 2700 gram, jenis kelamin perempuan, memiliki hecting 2. Sedangkan responden kedua Ny.An berusia 35 tahun dengan riwayat persalinan $\mathrm{P} 3 \mathrm{~A} 0$, pendidikan $\mathrm{SD}$, beragama islam, berat bayi lahir 3300 gram, jenis kelamin laki-laki, tidak memiliki hecting.

Berat bayi lahir pada partisipan pertama lebih kecil yaitu 2700 gram dibandingkan berat bayi lahir pada partisipan kedua yaitu 3300 gram. Dikaitkan dengan derajat inkontinensia urin yang diamati oleh partisipan dimana derajat partisipan pertama yaitu mendapatkan skor 10 (inkontinensia ringan-sedang) sebelum diberikan terapi kegel exercise, sedangkan partisipan kedua derajat inkontinensia lebih tinggi yaitu mendapatkan skor 13 (inkontinensia urin sedang). Hasil penelitian ini sejalan dengan hasil penelitian Fakhrizal dan Maryuni (2016) bahwa perbedaan berat bayi lahir berpengaruh terhadap resiko terjadi inkontinensia urin. ${ }^{4}$

Menurut penelitian yang dilakukan oleh Kurniati, et.al (2014) usia 20 sampai 35 tahun termasuk dalam usia dewasa awal. Penelitian tersebut menunjukkan bahwa semakin dewasa umur seseorang maka akan semakin matang dan lebih baik dalam berpikir dan bertindak. ${ }^{5}$ Hal ini ditunjukan oleh kedua partisipan dimana usia kedua partisipan adalah berusia 24 tahun dan 35 tahun. Usia tersebut termasuk dalam dewasa awal. Pada usia dewasa adalah usia produktif dimana frekuensi kehamilan dan melahirkan lebih tinggi sehingga dapat meningkatkan kejadian inkontinensia urin. ${ }^{6}$

Dilihat dari hasil penelitian yang dilakukan oleh peneliti menunjukan bahwa nilai akhir skoring inkontinensia urine pada responden pertama dengan skor 0 dihari ke6 dan partisipan dengan skor 0 dihari ke-7. Pada partisipan kedua berusia 35 tahun, dilihat dari hasil akhir skoring lebih lambat dari pada partisipan pertama yang berusia 24 tahun. Menurut Karjono, et.al, (2017) bahwa peningkatan usia merupakan salah satu faktor risiko melemahnya kekuatan otot dasar panggul, cenderung mengalami penurunan kekuatan otot dan menyebabkan inkontinensia urin. ${ }^{7}$

Menurut penelitian yang dilakukan oleh Kurniati, et.al (2014) bahwa semakin tingginya tingkat pendidikan seseorang 
maka semakin tinggi juga pemahaman seseorang dalam menerima informasi yang dapat menambah pengetahuannya. Hal ini terbukti dari hasil penelitian bahwa partisipan pertama memiliki pendidikan Sekolah Menengah Atas dan partisipan kedua pendidikan terakhirnya Sekolah Dasar. Partisipan pertama lebih cepat penurunan derajat inkontinensia urin dibandingkan partisipan kedua. ${ }^{5}$

Hasil penerapan latihan kegel exercise yang dilakukan kepada kedua partisipan bahwa riwayat persalinan partisipan pertama P1A0 dengan derajat inkontinensia urine sebelum diberikan terapi kegel exercise mendapatkan skor 10 (ringansedang) setelah dilakukan penerapan kegel exercise dan pada evaluasi hari ke-6 didapatkan skor 0 (tidak inkontinensia urin). Sedangkan pada partisipan kedua riwayat persalinan P3A0 dengan derajat inkontinensia urine sebelum diberikan penerapan kegel exercise mendapatkan skor 13 (sedang) dan setelah dilakukan penerapan kegel exercise dan dievaluasi pada hari ke-6 bahwa skor 2 (ringan) dan evaluasi hari ketujuh baru menunjukkan nilai skor 7 yaitu tidak inkontinensia urin. Hal ini juga sejalan dengan hasil penelitian Rahmawati \& Putri (2018) bahwa hampir seluruh responden yang mengalami inkontinensia urin adalah wanita dengan persalinan multipara. Semakin banyak persalinan pervaginam terjadi maka kekuatan otot panggul akan semakin melemah dan menyebabkan inkontinensia urin. $^{6}$

Kedua partisipan menunjukan penurunan derajat inkontinensia urine dikarenakan kedua responden melakukan tahap-tahap latihan kegel exercise dengan benar dan sesuai prosedur yang terdapat pada Standar Operasional Prosedur (SOP) tindakan. Selain Selain itu, penurunan derajat inkontinensia urine juga dikarenakan adanya dukungan dari keluarga dimana keluarga berusaha memanfaatkan latihan penerapan kegel exercise sebagai salah satu cara untuk menurunkan inkontinensia urine.
Penelitian ini sejalan dengan penelitian Rahmawat \& Putri (2018) bahwa ada pengaruh latihan kegel exercise terhadap tingkat inkontinensia urin pada ibu postpartum. Kegel exercise dapat meningkatkan resistensi uretra dengan memperkuat otot dasar panggul. Kegel exercise dapat menyebabkan hipertropi otot dasar panggul dan meningkatkan tekanan mekanik pada uretra dan memperbaiki fungsi sfingter uretra. ${ }^{3}$

\section{SIMPULAN DAN SARAN}

Berdasarkan hasil penelitian didapatkan kesimpulan yaitu sebelum diberikan intervensi kegel exercise bahwa pada partisipan pertama skor 10 (inkontinensia urin ringan-sedang) dan partisipan kedua skor 13 (inkontinensia urin sedang). Setelah diberikan intervensi kegel exercise bahwa pada partisipan pertama didapatkan skor 0 (tidak inkontinensia urin) pada hari keenam dan partisipan kedua didapatkan skor 0 (tidak inkontinensia urin) pada hari ketujuh. Direkomendasikan latihan kegel exercise pada ibu postpartum dapat diberikan untuk mencegah atau mengatasi inkontinensia urin.

\section{DAFTAR PUSTAKA}

1. Prawirohardjo S. Buku Acuan Nasional Pelayanan Kesehatan Maternal Dan Neonatal. Jakarta: PT Bina Pustaka; 2014.

2. Utami H, Suparni S, Ersila W. Waktu Pertama Buang Air Kecil (BAK) Pada Ibu Postpartum Yang Dilakukan Bladder Training. J Ilm Kesehat. 2014;6(1):96717.

3. Purnomo B. Dasar-Dasar Urologi. 3rd ed. Jakarta: CV Sagung Seto; 2012.

4. Fakhrizal E, Maryuni SW. Inkontinensia Urin Pascapersalinan dan Faktor-Faktor Risiko yang Memengaruhinya. J Ilmu Kedokt. 2017;10(2):98.

5. Kurniati CH, Wulan IS, Hikmawati I. Analisis Pengetahuan Dan Tindakan Senam Kegel Terhadap Penyembuhan Luka Perineum Pada Ibu Nifas Di Wilayah Kerja Puskesmas Purwokerto Selatan. Pharmacy. 2014;11(01):26-39.6. Rahmawati I, Putri RL. Pengaruh Senam Kegel Terhadap Tingkat Inkontinensia Urin Pada Wanita 
Pasca Melahirkan. Indonesian Journal Nursing Health Science. 2018;3(October):66-9.

7. Karjoyo JD, Pangemanan D, Onibala F. Pengaruh Senam Kegel Terhadap Frekuensi
Inkontinensia Urine Pada Lanjut Usia Di Wilayah Kerja Puskesmas Tumpaan Minahasa Selatan. J Keperawatan UNSRAT. 2017;5(1):107046. 